\title{
Vulnerabilities of nurses in an intensive care unit: an integrative review
}

\author{
Vulnerabilidades do enfermeiro em unidade de terapia intensiva: revisão integrativa \\ Vulnerabilidades del enfermero en unidad de cuidados intensivos: revisión integrativa
}

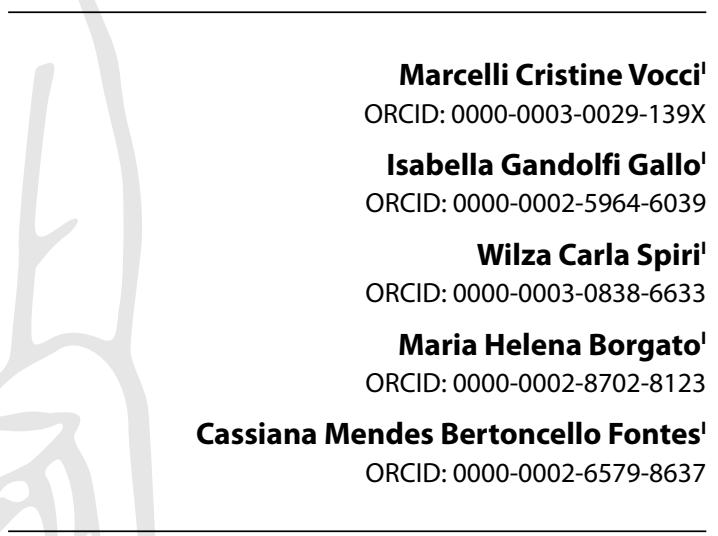

'Universidade Estadual Paulista. Botucatu, São Paulo, Brazil.

How to cite this article:

Vocci MC, Gallo IG, Spiri WC, Borgato MH, Fontes CMB.

Vulnerabilities of nurses in an intensive care unit: an integrative review. Rev Bras Enferm. 2021;74(3):e20200724. https://doi.org/10.1590/0034-7167-2020-0724

Corresponding author: Marcelli Cristine Vocci E-mail:marcellivocci@hotmail.com

EDITOR IN CHIEF: Dulce Barbosa ASSOCIATE EDITOR: Margarida Vieira

Submission: $08-24-2020$

Approval: 02-07-2021

\begin{abstract}
Objectives: to identify vulnerabilities of nurses who work in an intensive care unit. Methods: an integrative review was held from 2006 to 2019, with searches on the platforms/databases LILACS, BDENF, SciELO, MEDLINE, Scopus, CINAHL, and Web of Science. The theoretical framework of ergology, by Schwartz, was used and the guiding question "What are the main vulnerabilities of nurses who work in an intensive care unit"? Results: eleven articles were included. Five topics of vulnerabilities emerged: physical, emotional, communication process, care process, and organizational. We observed that the organizational vulnerability was kept as a common and intersection factor in developing the other four. Conclusions: vulnerabilities found have a relationship to the physical, emotional, communication, care process, and institution organization elements. The organization aspect intersected with the others, configuring itself as the core in this context.

Descriptors: Nurses; Review; Occupational Health; Work; Intensive Care Units.
\end{abstract}

\section{RESUMO}

Objetivos: identificar as vulnerabilidades dos enfermeiros atuantes em unidade de terapia intensiva. Métodos: foi realizada revisão integrativa no período de 2006 a 2019, com busca nas plataformas/bases de dados LILACS, BDENF, SciELO, MEDLINE, Scopus, CINAHL e Web of Science. Foi utilizado o referencial teórico da ergologia, de Schwartz, e a pergunta norteadora "Quais são as principais vulnerabilidades dos enfermeiros atuantes em unidade de terapia intensiva?". Resultados: onze artigos inclusos. Emergiram cinco temas de vulnerabilidades: física; emocional; processo de comunicação; processo de cuidar; e organizacional. Constatouse que a vulnerabilidade organizacional se manteve como um fator comum e de intersecção no desenvolvimento das outras quatro. Conclusões: as vulnerabilidades encontradas relacionaram-se aos elementos: físico, emocional; de comunicação; do processo de cuidar; e organizacional da instituição. $\mathrm{O}$ aspecto organizacional fez intersecção com os outros, configurando-se como nuclear nesse contexto.

Descritores: Enfermeiro; Revisão; Saúde do Trabalhador; Trabalho; Unidades de Terapia Intensiva.

\section{RESUMEN}

Objetivos: identificar las vulnerabilidades de los enfermeros actuantes en unidad de cuidados intensivos. Métodos: ha sido realizada revisión integrativa entre 2006 a 2019, con búsqueda en las plataformas/bases de datos LILACS, BDENF, SciELO, MEDLINE, Scopus, CINAHL y Web of Science. Ha sido utilizado el referencial teórico de la ergología, de Schwartz, y la pregunta de investigación "¿Cuáles son las principales vulnerabilidades de los enfermeros actuantes en unidad de cuidados intensivos?". Resultados: once artículos inclusos. Emergieron cinco temas de vulnerabilidades: física; emocional; proceso de comunicación; proceso de cuidar; y organizacional. Constató que la vulnerabilidad organizacional se mantuvo como un factor común y de intersección en el desarrollo de las otras cuatro. Conclusiones: las vulnerabilidades encontradas se relacionaron a los elementos: físico, emocional; de comunicación; del proceso de cuidar; y organizacional de la institución. El aspecto organizacional hizo intersección con los otros, configurándose como nuclear en eso contexto.

Descriptores: Enfermero; Revisión; Salud Laboral;Trabajo; Unidades de Cuidados Intensivos. 


\section{INTRODUCTION}

The intensive care unit (ICU) is characterized as a tense and stressful work environment that demands promptness and constant attention. Nurses who work in intensive care suffer the continuous influence of several stressors related to the work environment, such as exhaustive shifts, insufficient staff, and complexity of procedures. Due to these and other stressors, health professionals are more likely to develop occupational vulnerabilities ${ }^{(1)}$.

Nurses who work in intensive care units experience peculiar situations that may favor the appearance of various vulnerabilities. For example, the constant confrontation with death, ethical dilemmas, conflicts with personal values, feelings of helplessness, and also difficulty to establish boundaries with family members ${ }^{(2)}$.

Thinking on the term "vulnerability", is usually used to designate susceptibility to certain risks ${ }^{(3)}$. Yves Schwartz ${ }^{(4)}$, a philosopher specialist in the analysis of activity and pluridisciplinarity of labor situations, wrote about the work from the ergological point of view. From the philosophical and scientific point of view, ergology seeks to contemplate knowledge and productivity processes in all dimensions, with the goal to better understand the work and transform it ${ }^{(5)}$. The nursing team's work process consists of assisting the human being in different contexts, characterized by the categories that compose it and by its technical and social divisions ${ }^{(6)}$. In line with the dynamism of the nursing work, ergology arises as a theoretical-methodological framework in the perspective to analyze the strong relational aspect of the interaction of workers with the work environment, inherent to the profession ${ }^{(4,7)}$.

In nursing, when we understand "work" while an individual and collective construction, and valuing the main role of the worker in the organization and labor management processes, we understand that ergology may contribute to the assistance, construction of organization practices, and in the more flexible and humanized forms of management, as proposed by the National Policy for Humanization of Care and Management of the Unified Health System, for example ${ }^{(8)}$.

Thus, we developed this study with the justification of the need for knowledge and disclosure of the vulnerabilities of this profession. For that, we used theoretical references that subside the assistance and research in the nursing area, helping health professionals in the face of risk to their physical and mental health.

\section{OBJECTIVES}

To identify vulnerabilities of nurses who work in an intensive care unit.

\section{METHODS}

The integrative review is the complete and systematized analysis of scientific literature and publications in journals indexed regarding a definite issue, which purpose is to group results and allow the researcher to understand aspects that involve the studied theme ${ }^{(9)}$. The present review was run in four stages, described as follows.

\section{$1^{\text {st }}$ Stage - Identification of theme and construction of the guiding question}

The problem was delimited, and the descriptors were defined for the bibliographic search. The construction of the guiding question was based on the PICO strategy ${ }^{(10)}$, the acronym for: "P", which means Patient/Problem/Subject; "I", of Intervention; "C", of Control/ Comparison; and "O", of Outcomes (Chart 1).

Thus, we created the guiding question for the review: "What are the main vulnerabilities of nurses who work in an intensive care unit?".

Chart 1 - Strategy for the construction of the research question, Botucatu, São Paulo, Brazil, 2019

\begin{tabular}{|c|c|l|}
\hline Acronym & Definition & Description \\
\hline P & Problem/subject & Nurses who work in intensive care unit \\
\hline $\mathbf{I}$ & Intervention & Vulnerabilities under ergology framework \\
\hline $\mathbf{C}$ & $\begin{array}{c}\text { Control or } \\
\text { comparison }\end{array}$ & Vulnerabilities in all dimensions \\
\hline $\mathbf{O}$ & Outcomes & $\begin{array}{l}\text { Vulnerabilities in the work process of the } \\
\text { nurse who work in an intensive care unit }\end{array}$ \\
\hline
\end{tabular}

\section{$2^{\text {nd }}$ Stage - Stablishing of criteria for the selection of the identified articles}

The search was held from 2006 to 2019, under guidelines of a reference library on the platforms/databases Latin American and Caribbean Health Sciences Literature (LILACS), Medical Literature Analysis and Retrieval System Online (MEDLINE), Scientific Electronic Library Online (SciELO), Specialized Bibliographic Database in the Nursing Area of Brazil (BDENF), Scopus, CINAHL, and Web of Science. We used the descriptors from DeCS (Health Sciences Descriptors), and MeSH (Medical Subject Headings), in Portuguese and English languages (Chart 2).

Chart 2 - Search strategies I and II, including Boolean expressions in English and Portuguese languages, Botucatu, São Paulo, Brazil, 2019

\begin{tabular}{|l|l|}
\hline \multicolumn{2}{|l|}{ Search strategy I } \\
\hline I (English) & $\begin{array}{l}\text { (Intensive Care Units) AND (Vulnerability) AND (Team } \\
\text { Nursing) }\end{array}$ \\
\hline I (Portuguese) & $\begin{array}{l}\text { (Unidades de Terapia Intensiva) AND (Vulnerabilidade } \\
\text { em Saúde) AND (Equipe de Enfermagem) }\end{array}$ \\
\hline Search strategy II \\
\hline II (English) & (Vulnerability) AND (Intensive Care Units) AND (Nursing) \\
\hline II (Portuguese) & $\begin{array}{l}\text { (Vulnerabilidade) AND (Unidade de Terapia Intensiva) } \\
\text { AND (Enfermagem) }\end{array}$ \\
\hline
\end{tabular}

Inclusion criteria included the complete articles available free of charge and in full, in Portuguese, English, and/or Spanish languages, published in the period of the search. The exclusion criteria included articles not available free and were not in full, having the duplicates considered only once. The included articles were fully read and analyzed according to the guiding question of the review: "what are the main vulnerabilities of the nurses who work in an intensive care unit?". 


\section{$3^{\text {rd }}$ Stage - Evaluation of the studies included}

This stage consisted of a critical analysis of the studies, in which we identified the results that answered the guiding question. The selected articles were grouped in qualitative and quantitative studies to be analyzed by their respective instruments. We used the Strengthening the Reporting of Observational Studies in Epidemiology (STROBE) for the quantitative articles that score up to 22 points ${ }^{(11)}$; and, for the qualitative articles, we used the Consolidated Criteria for Reporting Qualitative Research (COREQ), score instrument that ranges from 1 to $32^{(12)}$. For the analysis of the evidence levels of the selected articles, we used the classification according to the criteria delimited by Melnyk and Fineout-Overholt ${ }^{(13)}$.

The selected articles were categorized in themes, according to the similarity of the conclusions of the analyzed studies.

\section{$4^{\text {th }}$ Stage - Interpretation of the results and synthesis of knowledge}

This is a discussion of the results, in which the data found are articulated to answer the guiding question. The analyzed content was shown in a chart way, with the synthesis of knowledge identified in each included article.

\section{RESULTS}

The selection process of the included articles was based on the following criteria: identification of duplicates among databases, reading of titles and abstracts, and full analysis of the article to answer the guiding question of the review. Then, we present the searches result.

After the use of inclusion and exclusion criteria, we selected 11 publications for the knowledge synthesis. In chart 3, we found characterization, analysis, and synthesis of the selected articles, including, for each article, the following variables: author/title/ year, design of the study, level of evidence according to the proper instrument for the evaluation, and the main findings.
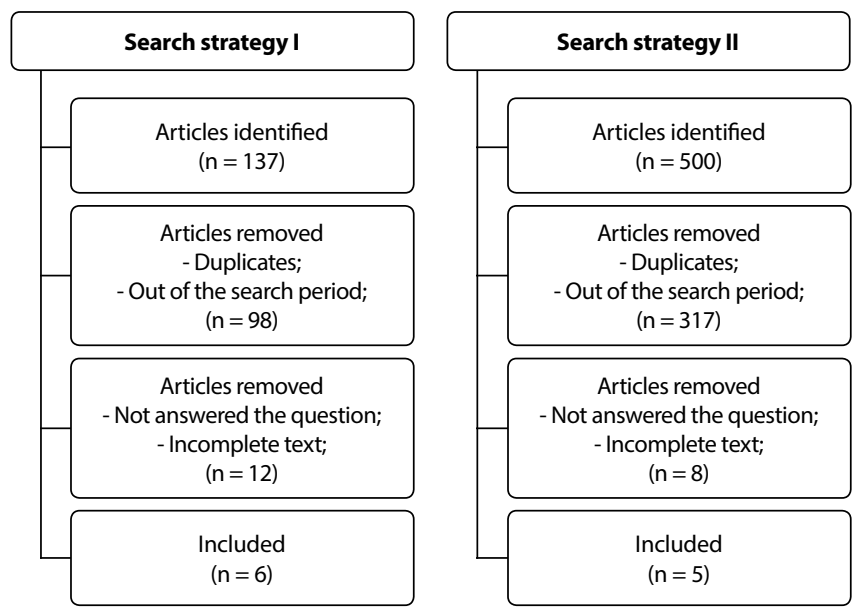

Figure 1 - Flowchart of the selected articles included in the integrative review, Botucatu, Sao Paulo, Brazil, 2019

The analysis and interpretation of data were carried out. Also, the themes were grouped and named as vulnerabilities elements (Chart 4).

With the themes identified, under the ergology framework, we could gather the vulnerabilities in physical risk, emotional and communication aspects, care process, and organizational. When reflecting and analyzing the spatial juxtapositions of the mentioned aspects, it was possible to group them in the form of a diagram. We observed that the organizational structure has an intersection core and runs through the diagrams in all directions and paths. Figure 2 shows the elaborated diagram.

Chart 3 - Included studies, Botucatu, São Paulo, Brazil, 2019

\begin{tabular}{|c|c|c|c|c|c|c|}
\hline Title ${ }^{(*)}$ & $\begin{array}{c}\text { Year/ } \\
\text { Country }\end{array}$ & $\begin{array}{l}\text { Design/ } \\
\text { number of } \\
\text { patients }\end{array}$ & Results & STROBE $^{\S}$ & COREQ ${ }^{\#}$ & Evidence \\
\hline $\begin{array}{l}\text { The body speaks: physical and } \\
\text { psychologic aspects of the stress in } \\
\text { nursing professionals }{ }^{(14)}\end{array}$ & $\begin{array}{c}2016 \\
\text { BRAZIL }\end{array}$ & $\begin{array}{c}\text { Qualitative } \\
n=21\end{array}$ & $\begin{array}{l}\text { The body suffers the manifestations of stress. Among the } \\
\text { symptoms most evident by the interviewees, physical } \\
\text { and mental fatigue and muscle pain stand out. }\end{array}$ & - & 30 & $\mathrm{VI}$ \\
\hline $\begin{array}{l}\text { Psychosocial factors and mental } \\
\text { workload: a reality perceived by } \\
\text { nurses in intensive care unit }{ }^{(15)}\end{array}$ & $\begin{array}{l}2015 \\
\text { CHILE }\end{array}$ & $\begin{array}{c}\text { Transversal } \\
n=111\end{array}$ & $\begin{array}{l}\text { The participants pointed out a high level of exposure } \\
\text { to psychosocial risks of psychological demand }(64 \%) \\
\text { and double shift ( } 57 \%) \text {. A medium to a high level of the } \\
\text { mental load was also observed. }\end{array}$ & 22 & - & IV \\
\hline $\begin{array}{l}\text { Risk factors to nurse safety in the } \\
\text { intensive care unit of a general } \\
\text { hospital }^{(16)}\end{array}$ & $\begin{array}{c}2015 \\
\text { BRAZIL }\end{array}$ & $\begin{array}{l}\text { Quantitative } \\
\qquad n=15\end{array}$ & $\begin{array}{l}\text { Nurses reported an excessive workload; precarious } \\
\text { working conditions; excessive noise in the work } \\
\text { environment; feeling pain in the body and episodes of } \\
\text { stress, triggered by living with pain, suffering and death. }\end{array}$ & 21 & - & $\mathrm{VI}$ \\
\hline $\begin{array}{l}\text { Quality of life in the work: } \\
\text { repercussions for the health of } \\
\text { intensive care nursing workers }{ }^{(17)}\end{array}$ & $\begin{array}{c}2014 \\
\text { BRAZIL }\end{array}$ & $\begin{array}{l}\text { Qualitative } \\
\qquad n=15\end{array}$ & $\begin{array}{l}\text { The excessive workload causes physical and } \\
\text { mental strain. This situation generates conflicts and } \\
\text { repercussions in the worker's health in the form of stress } \\
\text { and body pain. }\end{array}$ & - & 27 & $\mathrm{VI}$ \\
\hline $\begin{array}{l}\text { Medical malpractices and quality of } \\
\text { life related to the health of nursing } \\
\text { professionals in intensive care } \\
\text { units }^{(18)}\end{array}$ & $\begin{array}{c}2010 \\
\text { BRAZIL }\end{array}$ & $\begin{array}{c}\text { Transversal } \\
\mathrm{n}=94\end{array}$ & $\begin{array}{l}\text { In this study, } 19.1 \% \text { of the health professionals reported } \\
\text { having made medical malpractice in the month before } \\
\text { the survey. The health professionals who reported the } \\
\text { malpractice tended to have worsening health status. }\end{array}$ & 21 & - & $\mathrm{VI}$ \\
\hline
\end{tabular}




\begin{tabular}{|c|c|c|c|c|c|c|}
\hline Title ${ }^{(*)}$ & $\begin{array}{l}\text { Year/ } \\
\text { Country }\end{array}$ & $\begin{array}{l}\text { Design/ } \\
\text { number of } \\
\text { patients }\end{array}$ & Results & STROBE $^{\S}$ & COREQ ${ }^{\#}$ & Evidence \\
\hline $\begin{array}{l}\text { The stress of the nursing team in } \\
\text { the intensive care unit: the nurse } \\
\text { as a mediator }^{(19)}\end{array}$ & $\begin{array}{c}2006 \\
\text { BRAZIL }\end{array}$ & $\begin{array}{c}\text { Qualitative } \\
n=21\end{array}$ & $\begin{array}{l}\text { The main causes of stress reported were linked to } \\
\text { the difficulty of interpersonal relationships, lack of } \\
\text { human and material resources, work conditions, fair } \\
\text { distribution of the activities, professional respect, and } \\
\text { lack of psychological support service. }\end{array}$ & - & 20 & VI \\
\hline $\begin{array}{l}\text { The relationship between nurses } \\
\text { clinical competence and Burnout } \\
\text { in neonatal intensive care units }\end{array}$ & $\begin{array}{l}2016 \\
\text { IRAN }\end{array}$ & $\begin{array}{c}\text { Transversal } \\
\mathrm{n}=86\end{array}$ & $\begin{array}{l}\text { Regarding the nurses' strain, results shown emotional } \\
\text { exhaustion, and an inverse association between } \\
\text { burnout at work and clinical competence, so that } \\
\text { greater clinical competence generates less burnout } \\
\text { at work. }\end{array}$ & 22 & - & VI \\
\hline $\begin{array}{l}\text { Impact of noise on nurses in } \\
\text { pediatric intensive care units }\end{array}$ & $\begin{array}{l}2015 \\
\text { USA }\end{array}$ & $\begin{array}{c}\text { Transversal } \\
n=15\end{array}$ & $\begin{array}{l}\text { The levels of noise in the intensive care units exceed } \\
\text { the recommended limits. There was a statistically } \\
\text { significant correlation of noise with the increase in } \\
\text { heart rate of professionals. }\end{array}$ & 22 & - & VI \\
\hline $\begin{array}{l}\text { The need to nurse the nurse: } \\
\text { emotional labor in neonatal } \\
\text { intensive care }{ }^{(22)}\end{array}$ & $\begin{array}{l}2014 \\
\text { USA }\end{array}$ & $\begin{array}{l}\text { Qualitative } \\
n=114\end{array}$ & $\begin{array}{l}\text { Health professionals mainly reported the lack } \\
\text { of recognition at work, in addition to the lack of } \\
\text { emotional support. }\end{array}$ & - & 30 & V \\
\hline $\begin{array}{l}\text { Attitude of nurses in an intensive } \\
\text { care unit in the face of a } \\
\text { malpractice: an approach based } \\
\text { on bioethical references }{ }^{(23)}\end{array}$ & $\begin{array}{c}2010 \\
\text { BRAZIL }\end{array}$ & $\begin{array}{l}\text { Qualitative } \\
n=14\end{array}$ & $\begin{array}{l}\text { The responsibility in the face of professional } \\
\text { malpractice supposes the recognition of nurses' } \\
\text { vulnerabilities. }\end{array}$ & - & 23 & VI \\
\hline $\begin{array}{l}\text { The nurses experience of barriers } \\
\text { to safe practice in the neonatal } \\
\text { intensive care unit in Thailand }{ }^{(24)}\end{array}$ & $\begin{array}{c}2006 \\
\text { THAILAND }\end{array}$ & $\begin{array}{c}\text { Qualitative } \\
n=27\end{array}$ & $\begin{array}{l}\text { Multiple limitations and vulnerabilities were } \\
\text { widely associated with the lack of personnel, } \\
\text { human susceptibility to malpractices, team } \\
\text { miscommunication, and multiple designated tasks. }\end{array}$ & - & 30 & V \\
\hline
\end{tabular}

Note: ${ }^{5}$ STROBE - Strengthening the Reporting of Observational Studies in Epidemiology; " COREQ - Consolidated Criteria for Reporting Qualitative Research.

Chart 4 - Themes emerged from the analysis of the articles included in the review, Botucatu, São Paulo, Brazil, 2019.

\begin{tabular}{|c|c|}
\hline Themes & $\begin{array}{l}\text { Author(s), year of } \\
\text { publication }\end{array}$ \\
\hline $\begin{array}{l}\text { Physical fatigue and body aches } \\
\text { due to excessive load and double } \\
\text { working hours. }\end{array}$ & $\begin{array}{l}\text { Rodrigues et al. }(2016)^{(14)} \\
\text { Coronetti et al. }(2006)^{(19)} \\
\text { Soroush et al. }(2017)^{(20)} \\
\text { Jirapaet et al. }(2006)^{(24)}\end{array}$ \\
\hline $\begin{array}{l}\text { Mental burden related to living } \\
\text { with suffering and death. }\end{array}$ & $\begin{array}{l}\text { Rodrigues et al. (2016)(14) } \\
\text { Ceballos-Vásquez et al. }(2015)^{(15)} \\
\text { Ramos et al. }(2014)^{(17)}\end{array}$ \\
\hline $\begin{array}{l}\text { Psychological demand of the } \\
\text { health professionals and lack of } \\
\text { support by the institution. }\end{array}$ & $\begin{array}{l}\text { Ceballos-Vásquez et al. (2015)(15) } \\
\text { Coronetti et al. }(2006)^{(19)} \\
\text { Cricco-Lizza et al. }(2014)^{(23)}\end{array}$ \\
\hline $\begin{array}{l}\text { Excessive load and poor work } \\
\text { conditions, such as lack of human } \\
\text { and material resources. }\end{array}$ & $\begin{array}{l}\text { Albuquerque et al. }(2015)^{(16)} \\
\text { Coronetti et al. }(2006)^{(19)}\end{array}$ \\
\hline $\begin{array}{l}\text { Excessive noise in the work } \\
\text { environment, which leads to } \\
\text { constant stress. }\end{array}$ & $\begin{array}{l}\text { Albuquerque et al. (2015)(17) } \\
\text { Watson et al. }(2015)^{(22)}\end{array}$ \\
\hline $\begin{array}{l}\text { Medical malpractices, especially in } \\
\text { medication, presupposes a worse } \\
\text { state of mental health for the } \\
\text { professional. }\end{array}$ & $\begin{array}{l}\text { Pelicciotti et al. }(2010)^{(19)} \\
\text { Coli et al. }(2010)^{(24)} \\
\text { Jirapaet et al. }(2006)^{(25)}\end{array}$ \\
\hline
\end{tabular}

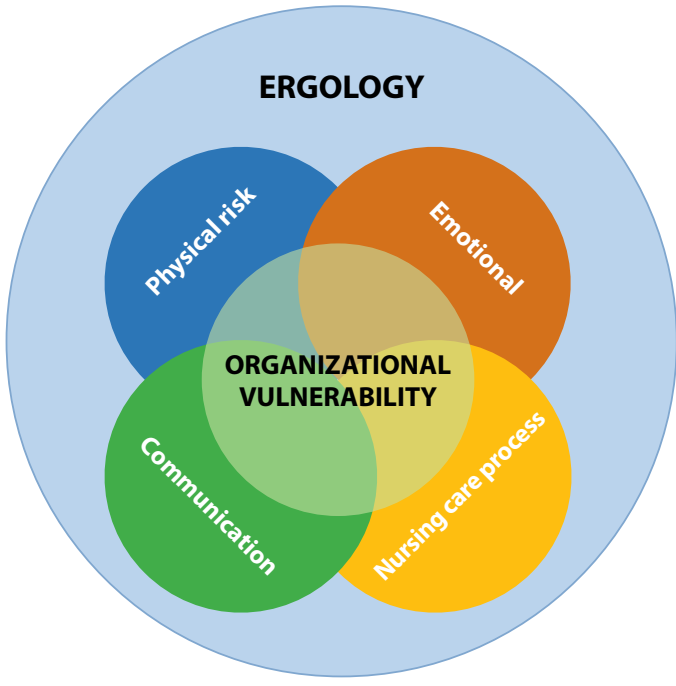

Figure 2 - Intersection diagram among the vulnerabilities identified, Botucatu, São Paulo, Brazil, 2019

\section{DISCUSSION}

With the search I and II, we had complementary findings and, based on the guiding question of the review, we got the main highlighted vulnerabilities of the nurses related to poor work conditions, psychological factors; mental load; body pain; the stressful work routine; and professional mistakes. 
Burnout syndrome, is a psychosocial pathology frequently diagnosed in nurses that is associated with response to chronic work stress and professional exhaustion ${ }^{(25-26)}$. The health team, especially the nurse team, goes through high daily wear, making it vulnerable to the occurrence of this syndrome, especially when associated with stress and the complexity of the care provided ${ }^{(16,20)}$.

The stressful environment added to the decline in mental health may increase the malpractices since critically ill patients receive considerably more proceedings than the hospitalized in general care units ${ }^{(18,23)}$. In a trial carried out in Ohio, in 2015, an increase in nurse's heart rate was noticed in response to sounds above 75 decibels emitted by appliances, screaming, moaning, talking, and various other noises, suggesting that intermittent noise can affect the emotional and communication process ${ }^{(21)}$.

Also, other factors were identified as stressors, as the lack of guidance when facing situations of death, insufficient human and material resources, lack of organization in the workplace, unpreparedness for technological evolution, and, mainly, the relationship conflict between professionals and the institution $^{(14-15,19)}$. Thus, the employer institution has a great contribution to professional exhaustion and development of vulnerabilities. Currently, the reality of nurses reveals an insufficient dimensioning of human resources, which leads to an excessive workload and makes them prone to psychological problems $s^{(17,24)}$.

Regarding these mentioned vulnerabilities, the Cricco-Lizza's study discusses interventions and strategies to assist the professional nurse, such as physical exercises, rest, leisure, spiritual renewal. It also indicates the importance of a psychological support network, provided by the employer institution ${ }^{(22)}$.

Relationships in the work environment are multi/interconnected and, according to Schwartz ${ }^{(4)}$, involve all the directions and all their constitutive elements to each other: health team professionals, equipment, organizational structure of the institution, critical condition patients, and their family members. Thus, vulnerabilities arise from these interactions as multiple access routes ${ }^{(27)}$.

The ergologic framework provided the identification of vulnerabilities to analyze the different dimensions of the nurses in clinical practice in a critical environment ${ }^{(4)}$. With themes identified, we could gather vulnerabilities under the ergology framework, and analyze the spatial juxtapositions of the aspects mentioned. Thus, the diagram (Figure 2) proposed and constructed by the authors shows an organizational structure as the intersection nucleus that permeates all directions and directions, referring to employing institutions.
Regarding the perceived need for institutional support, we observed that the highlighted vulnerabilities are strongly related to the labor aspects, such as the excess workload, and the unfair distribution of activities due to the lack of human resources. The study shows that when health professionals do not have the necessary conditions to provide safe assistance, it may result in exhaustion and stress. Furthermore, the lack of material favors the occupational risk, affecting their safety and that of the patient ${ }^{(19,28)}$.

Noise in interpersonal communication, coupled with the lack of human resources, can affect the quality of care provided. The discomfort caused by this scenario leads to a conflicting relationship with patients, as if they were the cause of this situation. Poor working conditions can cause illness and suffering, as the pleasant and successful performance of this activity is hampered ${ }^{(5)}$.

The results of this review emphasize the significant relationship between the stress and the work conditions of the nursing professionals, as well as highlight the professional malpractices as an important consequence of such vulnerabilities. Therefore, we emphasize the need for a welcoming institutional environment, identification of organizational issues, and offer of a psychological support network to the health professionals who may need it.

\section{Limitations of the study}

Limitations are related to the restriction of searches in English, Portuguese, and Spanish languages, and the exclusion of free articles not available in full.

\section{Contributions to the Field}

It is an innovative theme for nursing, enabling the understanding and identification of vulnerabilities of the intensive care nurse from an ergologic perspective, which allows the development of strategies for a healthier work environment.

\section{CONCLUSIONS}

Eleven articles were included in the review, which allowed the identification of vulnerability aspects of nurses of an intensive care unit. The vulnerabilities of such nurses are related to the physical, emotional, communication, care process, and institution organization elements. We highlight that the organization aspect intersected with the others, configuring itself as the core in this context.

\section{REFERENCES}

1. Khamisa N, Oldenburg B, Peltzer K, llic D. Work related stress, burnout, job satisfaction and general health of nurses. Int J Environ Res Public Health. 2015;12(1):652-66. https://doi.org/10.1111/ijn.12455

2. Benzies KM, Shah V, Aziz K, Lodha A, Misfeldt R. The health care system is making 'too much noise' to provide family-centred care in neonatal intensive care units: Perspectives of health care providers and hospital administrators. Intensive Crit Care Nurs. 2019;50:44-53. https://doi.org/10.1016/j.iccn.2018.05.001

3. Angel S, Vatne S. Vulnerability in patients and nurses and the mutual vulnerability in the patient-nurse relationship. J Clin Nurs. 2017;26(9-10):142837. https://doi.org/10.1111/jocn.13583

4. Schwartz Y. Conceptualizing the work, the visible and invisible. Trab Educ Saúde. 2011; 9:19-45. https://doi.org/10.1590/S1981-77462011000400002

5. Lima ELN, Bianco MF. Análise de situações de trabalho: gestão e os usos de si dos trabalhadores de uma empresa do ramo petrolífero. Rio de Janeiro: Cad EBAPE.BR. 2009;7(4):632-58. https://doi.org/10.1590/S1679-39512009000400008 
6. Forte ECN, Pires DEP, Martins MMFPS, Padilha MICS, Schneider DG, Trindade LL. Work process: a basis for understanding nursing errors. Rev Esc Enferm USP. 2019;53:e03489. https://doi.org/10.1590/S1980-220X2018001803489

7. Holz EB, Bianco MF. Ergology: a possible approach to organizational studies of work. Cad. EBAPE.BR. 2014; 12:494-512. https://doi. org/10.1590/1679-39519106

8. Ministério da Saúde (BR). Secretaria de Atenção a Saúde. Política Nacional de Humanização da Atenção e Gestão do SUS. Gestão participativa e cogestão. Brasília, 2009. Available from: https://deivissonlopes.files.wordpress.com/2013/07/humanizasus_gestao_participativa_cogestaottdfd.pdf

9. Mendes KD, Silveira RC, Galvão CM. Integrative literature review: a research method to incorporate evidence in health care and nursing. Texto Contexto Enferm. 2008;17(4):758-64. https://doi.org/10.1590/S0103-21002012000600022

10. Mamédio C, Santos DC, Andrucioli C, Pimenta M, Roberto M, Nobre C. The PICO strategy for the research question construction and evidence search. Rev Latino-Am Enfermagem. 2007;15(3):508-11. https://doi.org/10.1590/S0104-11692007000300023

11. Malta M, Cardoso LO, Bastos FI, Magnanini MMF, Silva CMF. STROBE initiative: guidelines on reporting observational studies. Rev Saúde Pública. 2010;44:559-65. https://doi.org/10.1590/S0034-89102010000300021

12. Tong A, Sainsbury P, Craig J. Consolidated Criteria for Reporting Qualitative Research (COREQ):a 32-item checklist for interviews and focus groups. Int J Qual Health Care. 2007;19:349-57. https://doi.org/10.1093/intghc/mzm042

13. Melnyk BM, Fineout-Overholt E. Making the case for evidence-based practice. In: Melnyk BM, Fineout-Overholt E. Evidence-based practice in nursing \& healthcare: a guide to best practice. Philadelphia: Lippincot Williams \& Wilkins; 2005.p.3-24.

14. Rodrigues CCFM, Santos VEP. The body speaks: physical and psychological aspects of stress in nursing professionals. Rev Pesqui: Cuid Fundam. 2015;7(4):3587-96. https://doi.org/10.9789/2175-5361.2016.v8i1.3587-3596

15. Vásquez PC, González R, Fernaud H, Cabrera D, Klijn P, Moreno B. Psychosocial factors and mental work load: a reality perceived by nurses in intensive care units. Rev Latino-Am Enfermagem. 2015;23(2):315-22. https://doi.org/10.1590/0104-1169.0044.2557

16. Albuquerque $\mathrm{SGE}$, Castro RD, Ferreira GLS, Oliveira KL. Fatores de risco à segurança do enfermeiro na unidade de terapia intensiva de um hospital geral. Rev Bras Ciênc Saúde. 2015;19:135-42. https://doi.org/10.4034/RBCS.2015.19.02.08

17. Ramos EL, Souza VDO, Gonçalves FGA, Pires AS, Santos DM. Quality of work life: repercussions for the health of nursing worker in intensive care. Rev Pesqui: Cuid Fundam. 2014;6(2):571-83. https://doi.org/10.9789/2175-5361.2014v6n2p571

18. Pelliciotti JSS, Kimura M. Medications errors and health-related quality of life of nursing professionals in intensive care units. Rev Latino-Am Enfermagem. 2010;18(6):1062-9. https://doi.org/10.1590/S0104-11692010000600004

19. Coronetti A, Nascimento ERP, Barra DCC, Martins JJ. The stress of the team of nursing in the intensive care unit: the nurse mediating. ACM Arq Catarin Med. 2006;35(4):36-43. Available from: https://www.acm.org.br/revista/pdf/artigos/394.pdf

20. Soroush F, Boroujeni AZ. The relationship between nurses' clinical competence and burnout in neonatal intensive care units. Iran J Nurs Midwifery Res. 2016;21(4):424-9. https://doi.org/10.4103/1735-9066.185596

21. Watson J, Kinstler A, Vidonish WP, Wagner M, Lin L, Davis KG, et al. Impact of noise on nurses in pediatric intensive care. Am J Crit Care. 2015; 24(5):377-84. https://doi.org/10.4037/ajcc2015260

22. Cricco-lizza R. The need to nurse the nurse: emotional labor in neonatal intensive care. Qual Health Res. 2014;24(5):615-28. https://doi. org/10.1177/1049732314528810

23. Coli RCP, Anjos MF, Pereira LL. The attitudes of nurses from an intensive care unit in the face of errors: an approach in light of bioethics. 2010;18(3):324-30. https://doi.org/10.1590/S0104-11692010000300005

24. Jirapaet V, Jirapaet $\mathrm{K}$, Sopajaree $\mathrm{C}$. The nurses' experience of barriers to safe practice in the neonatal intensive care unit in Thailand. J Obstet Gynecol Neonatal Nurs. 2006;35(6):746-54. https://doi.org/10.1111/j.1552-6909.2006.00100.x

25. Ding Y, Yang Y, Yang X, Zhang T, Qiu X, He X, et al. The mediating role of coping style in the relationship between psychological capital and burnout among Chinese nurses. PLoS One [Internet]. 2015;10(4):1-14. https://doi.org/10.1371/journal.pone.0122128

26. Vasconcelos EM, Martino MMF, França SPS. Burnout and depressive symptoms in intensive care nurses: relationship analysis. Rev Bras Enferm. 2018;71(1):135-41. https://doi.org/10.1590/0034-7167-2016-0019

27. Vieira LN, Sá FM, Spiri WC, Borgato MH, Fontes CMB. The experience of nurses' vulnerability in pediatric intensive care. Enferm Foco. 2019;10(5):58-64. https://doi.org/10.21675/2357-707X.2019.v10.n5.2663

28. Oliveira EM, Barbosa RL, Andolhe R, Eiras FRC, Padilha KG. Nursing practice environment and work satisfaction in critical units. Rev Bras Enferm. 2017;70(1):73-80. https://doi.org/10.1590/0034-7167-2016-0211 